\title{
HUBUNGAN ISLAM DAN BUDAYA DALAM TRADISI BA-AYUN MAULID DI MASJID BANUA HALAT KABUPATEN TAPIN, KALIMANTAN SELATAN
}

\author{
THE RELATIONSHIP BETWEEN THE ISLAM AND CULTURE IN BA-AYUN- \\ MAULID TRADITIONSAT BANUA HALAT MOSQUE TAPIN REGENCY, SOUTH \\ KALIMANTAN \\ Wajidi \\ Balitbangda Provinsi Kalimantan Selatan \\ Jalan Aneka Tambang Trikora, Kawasan Perkantoran Pemerintah Provinsi Kalimantan Selatan, \\ Banjarbaru \\ e-mail: wajidi.amberi@gmail.com
}

\begin{abstract}
Abstrak
Ba-ayun Maulid di Masjid Banua Halat menarik untuk dikaji karena memperlihatkan adanya hubungan antara Islam dan budaya. Yang menjadi permasalahan dalam penelitian ini adalah bagaimana hubungan antara Islam dan budaya pada upacara ba-ayun maulid. Kajian ini bertujuan untuk: (1) Mengetahui gambaran pelaksanaan upacara ba-ayun maulid di Masjid Banua Halat; (2) Mengetahui pengaruh tradisi Pra-Islam dalam upacara ba-ayun maulid di Masjid Banua Halat; (3) Mengetahui latar belakang munculnya pengaruh tradisi Pra-Islam pada upacara ba-ayun maulid di Masjid Banua Halat. Lokasi penelitian mengambil tempat di desa Banua Halat Kabupaten Tapin. Secara metodologis, penelitian ini merupakan penelitian deskriptif kualitatif dengan pendekatan antropologis, sejarah, budaya dan keagamaan. Hasil penelitian menunjukkan bahwa Desa Banua Halat dahulunya pernah dihuni komunitas pra-Islam yang tinggal cukup lama dan berlanjut sampai datangnya pengaruh Islam. Ketika Islam berkembang di wilayah ini, terjadilah interaksi Islam dengan kepercayaan lama sebagaimana tercermin dalam upacara $b a$ ayun maulid. Upacara ba-ayun maulid sebenarnya berasal tradisi lama yakni upacara bapalas bidan atau ma-ayun anak sebagai sebuah tradisi yang berlandaskan kepada kepercayaan Kaharingan. Ketika Islam masuk dan berkembang di Banua Halat, upacara bapalas bidan tidak lantas hilang dan malah mendapat pengaruh unsur Islam sebagaimana terlihat pada upacara $b a$ ayun maulid yakni upacara mengayun anak sambil membaca syair maulid yang dilaksanakan bersamaan dengan perayaan maulid Nabi Besar Muhammad SAW.
\end{abstract}

Kata kunci: Ba-ayun maulid, Masjid Banua Halat, Islam, budaya.

\begin{abstract}
Ba'ayun Maulid in Banua Halat Mosque is interesting study, because the ceremony shows the interaction between Islam and the local culture. The main problem in this research is to know the relationship between Islam and the culture in the Ba-ayun Mawlid ceremony. This study aims to: (1) Knowing the implementation overview Ba-ayun Maulid ceremony at Banua Halat Mosque; (2) Determine the influence of pre-Islamic traditions in the Ba-ayun Maulid ceremony at Banua Halat Mosque; (3) Knowing the background of the pre-Islamic tradition's effect in Ba-ayun Mawlid ceremony at Masjid Banua Halat. Location of this research took place in the village of Halat Banua Tapin regency. This research used descriptive-qualitative and multidimensional approaches, which consists of anthropological, historical, cultural and religious perspective. The results of this study indicate that the Bапиа Halat village was once inhabited pre-Islamic community. The community settled in a long periods until the advent of Islamic influence. When
\end{abstract}


Islam developed in this region, there was interaction between Islam with the old religion as reflected in the Ba-ayun Maulid ceremony. The Ba-ayun Maulid ceremony that held at Banua Halat Mosque remnants of the old religion is still there, but has been acculturated to Islam. The ceremony is originated by the old tradition, Bapalas bidan or ma-ayun anak as the tradition based on the Kaharingan belief. When Islam came and develop in Banua Halat, the Bapalas bidan ceremony is not vanished, hence it got the Islam influence as reflected in Ba-ayun Maulid ceremony, in the process of Ma-ayun anak while reciting maulid verse, together with the celebration of Maulid of Profet Muhammad SAW.

Keywords: ba-ayun maulid, Banua Halat Mosque, Islam, culture.

\section{A. PENDAHULUAN}

Tradisi ba-ayun maulid merupakan kegiatan mengayun anak (ma-ayun anak) yang dilaksanakan bersamaan dengan peringatan Maulid Nabi Muhammad SAW (12 Rabiul Awal 1432 H). Ba-ayun asal katanya "ayun' yang diartikan "melakukan proses ayunan". Bayi yang mau ditidurkan dalam ayunan biasanya akan diayun oleh ibunya. Sedangkan maulid atau milad dalam bahasa Arab berarti hari lahir. Maulid di sini maksudnya adalah maulid nabi (mawlid an-nabī) yang artinya hari lahir Nabi Muhammad SAW. Dengan demikian, ba-ayun maulid diartikan sebagai kegiatan mengayun bayi atau anak sambil membaca syair maulid atau bersamaan dengan peringatan maulid Nabi Muhammad SAW.

Pada masyarakat Banjar di Kalimantan Selatan, tradisi ba-ayun maulid bukan sekadar budaya yang diwarisi dan dipraktikkan secara turun temurun, melainkan kini juga menjadi atraksi wisata yang menarik seperti yang berlangsung di Masjid Al-Mukarromah Banua Halat (seterusnya disebut Masjid Banua Halat), Kabupaten Tapin.

Sebagai bagian dari upacara daur hidup, tradisi ba-ayun maulid di Masjid Banua Halat menarik untuk dikaji karena memperlihatkan adanya interaksi atau persinggungan antara Islam dan budaya (kepercayaan lama). Persinggungan itu dapat dipahami jika kita melihat proses Islamisasi pada masyarakat Banjar praIslam yang tidak serta merta menghapus pelbagai upacara yang terkait dengan kepercayaan lama, melainkan memberikan atau mengisinya dengan nilai-nilai Islam.
Yang menjadi permasalahan adalah bagaimana gambaran hubungan antara Islam dan budaya pada upacara ba-ayun maulid?

Berdasarkan permasalahan tersebut di atas, kajian ini bertujuan untuk: (1) Mengetahui gambaran pelaksanaan upacara ba-ayun maulid di Masjid Banua Halat; (2) Mengetahui pengaruh tradisi Pra-Islam dalam upacara ba-ayun maulid di Masjid Banua Halat; (3) Mengetahui latar belakang munculnya pengaruh tradisi Pra-Islam pada upacara ba-ayun maulid di Masjid Banua Halat.

Untuk memahami bagaimana gambaran hubungan antara Islam dan budaya dalam tradisi ma-ayun maulid dapat dilihat dengan mengikut kepada kerangka teori berkenaan dengan interaksi atau dialektika antara agama dan budaya sebagaimana yang dijelaskan oleh Kuntowijoyo, Clifford Geertz, dan Koentjaraningrat. Menurut Kuntowijoyo (2001: 196), sebagai sebuah kenyataan sejarah, agama dan kebudayaan dapat saling memengaruhi karena pada keduanya terdapat nilai dan simbol. Berbagai upacara daur selalu mempunyai beragam simbol, dan karena memang simbol itu sendiri bagian dari kebudayaan.

Sementara itu Clifford Geertz (1995:3) menyatakan kebudayaan adalah suatu pola makna-makna yang diteruskan secara historis yang terwujud dalam simbol-simbol. Manusia menciptakan simbol-simbol yang mampu menjadi media penyimpan makna atau nilai budaya, sehingga proses meneruskan nilai budaya dapat berlangsung terus. Simbol yang tergambar dalam berbagai ritus dan 
kebudayaan dianggap pula sebagai media komunikasi dengan alam lain yang dipercaya menguasai kehidupan manusia, dan di sinilah pertemuan antara nilai budaya, tradisi, simbol, mitos dengan sistem religi dan upacara keagamaan. Menurut Bascom (Danandjaja, 1986:50) mite atau mitos adalah cerita prosa rakyat yang dianggap benar-benar terjadi serta dianggap suci oleh yang empunya cerita.

Mengacu

Koentjaraningrat pada

hubungan Islam dan budaya juga dapat dilihat dari akibat adanya perjumpaan kebudayaan (culture contact) yang disebut dengan akulturasi (acculturation) yakni proses sosial yang timbul bila suatu kelompok manusia dalam suatu masyarakat dengan suatu kebudayaan tertentu dihadapkan dengan unsur-unsur kebudayaan asing dengan sedemikian rupa, sehingga unsur-unsur kebudayaan asing itu lambat laun diterima dan diolah ke dalam kebudayaan sendiri tanpa menyebabkan hilangnya kepribadian kebudayaan itu sendiri.

Upacara ba-ayun maulid adalah sebuah tradisi yang diwarisi dari masa lalu. Untuk memahaminya dapat mengacu pada pendapat Shils (Sztompka, 2008: 69-70) yang menyatakan tradisi berarti segala sesuatu yang disalurkan atau diwariskan dari masa lalu ke masa kini. Basis tradisi adalah kaitan antara masa kini dan masa lalu yang dilalui melalui proses yang tidak terputus, sehingga tradisi demikian disebut juga dengan tradisi sejarah.

Lebih lanjut Piotr Sztompka (2008) menyatakan tradisi muncul melalui dua cara, yakni dari bawah sebagai tradisi asli yang sudah ada di masa lalu dan dari atas (penguasa) berupa tradisi buatan. Ba-ayun maulid adalah tradisi asli yang memiliki daya tarik yang diperlihatkan masyarakat pendukung melalui perhatian, ketakziman, dan kekaguman.

Adanya perhatian, ketakziman, kekaguman yang terwujud dalam bentuk upacara, ziarah atau sikap mental dan perasaan manusianya terhadap benda- benda tertentu merupakan bentuk yang menghasilkan kesakralan terhadap suatu tradisi. Ketakziman dan kekaguman itu terjadi karena benda maupun upacara tertentu itu dianggap atau pun dirasakan diselimuti oleh berbagai mitos, misteri, simbol, kekuatan magis yang terkait dengan kepercayaan yang diyakininya. Sebagaimana dikatakan Elizabeth K. Nottingham (2002:9) nilai kesakralan bukan ditentukan oleh bendanya melainkan sikap atau perasaan (manusianya) yang memperkuat kesakralan benda-benda itu.

Pengaruh agama dapat melanggengkan sebuah tradisi melalui pemaknaan yang dikaitkan dengan keagamaan. Oleh karena itu, sistem religi atau upacara keagamaan merupakan salah satu unsur kebudayaan yang paling stabil sifatnya terhadap perubahan. Jika dikaitkan dengan ba-ayun maulid, sebuah upacara yang sebelumnya dipraktikkan berdasarkan kepercayaan lama dapat menjadi sebuah tradisi dalam agama Islam karena dalam pelaksanaanya diberi anasir Islam.

Meski mendapat pengaruh Islam, tidak semua tradisi yang terkait dengan agama merupakan ajaran dari agama itu sendiri. Sebagaimana ditegaskan Alfani Daud (1997:6-7) bahwa praktik-praktik keagamaan yang merupakan bagian dari religi komunitas pada masyarakat Banjar tidaklah seluruhnya dapat dicari referensinya dalam ajaran Islam. Asal mula praktik keagamaan itu dapat ditelusuri dari sisa-sisa kepercayaan dan praktik keagamaan religi suku, Hindu, dan Budha yang pernah berkembang jauh sebelum masuknya Islam ke kawasan ini. Ketika Islam berkembang di wilayah ini maka terjadilah perpaduan antara unsur Islam dengan kepercayaan lama yang terungkap dalam praktik-praktik keagamaan suatu komunitas dalam masyarakat Banjar.

\section{B. METODE PENELITIAN}

Lokasi penelitian mengambil tempat di Desa atau Kampung Banua Halat Kabupaten Tapin, khususnya di Masjid Al- 
Mukarromah (populer disebut Masjid Banua Halat) yang menjadi tempat penyelenggaraan upacara ba-ayun maulid.

Banua Halat dahulunya merupakan kampung tua yang merepresentasikan asal ritual dan akulturasi antara Islam dan budaya dalam upacara ba-ayun maulid. Pemilihan desa tua Banua Halat dimaksudkan guna melacak pemahaman yang lebih luas terhadap asal muasal atau interaksi antara agama dan budaya pada upacara ba-ayun maulid.

Jenis penelitian ini merupakan penelitian deskriptif yang bermaksud untuk menggambarkan keberadaan upacara $b a$ ayun maulid di Banua Halat. Data primer dan sekunder, baik berupa peninggalanpeninggalan (relics atau remain) dan catatan-catatan (records) (Sjamsuddin, 2012:76) dikumpulkan menggunakan kombinasi teknik-teknik pengumpulan data, yakni wawancara, pengamatan/observasi, studi kepustakaan, dokumentasi.

Untuk memperoleh deskripsi digunakan pendekatan deskriptif kualitatif berdasarkan informasi atau keterangan yang diberikan oleh para informan, hasil pengamatan langsung yang dilaksanakan penulis pada saat pelaksanaan upacara $b a$ ayun maulid, Kamis 25 Februari 2010 (11 Rabiul Awal $1431 \mathrm{H}$, serta sumber sekunder yakni hasil penelitian Abbas et al. (1994/1995).

Pada upacara ba-ayun maulid terdapat dua aspek budaya, yakni tangible dan intangible. Menurut Edy Sedyawati (2012:161) aspek intangible antara lain berkenaan dengan konsep, perlambang, kebermaknaan, fungsi, dan isi pesan yang terkandung di dalamnya. Untuk memahami aspek intangible ini serta keterkaitan (akulturasi) antara agama dan budaya dalam upacara ba-ayun maulid digunakan pendekatan antropologis, sejarah, budaya dan keagamaan. Pendekatan antropologis adalah pendekatan kebudayaan, artinya agama dipandang sebagai bagian dari kebudayaan, baik wujud idea atau gagasan yang dianggap sebagai sistem norma dan nilai yang dimiliki oleh anggota masyarakat, yang mengikat seluruh anggota masyarakat.

Pendekatan antropologi budaya dimaksudkan untuk melihat adanya realitas budaya masyarakat di Banua Halat baik budaya dilihat dari komponen isinya (tujuh unsur kebudayaan universal) maupun komponen wujud seperti sistem budaya berupa ide dan gagasan, maupun sistem sosial berupa tingkah laku dan tindakan. Melalui pendekatan tersebut maka kajian akulturasi antara Islam dan budaya di sini tidak dimaksudkan untuk menjustifikasi upacara tradisional atau unsur kepercayaan lama dalam Upacara ba-ayun maulid di Banua Halat dengan syariat atau akidah yang diyakini masyarakat pendukungnya.

\section{HASIL DAN BAHASAN}

\section{G ambaran U mum Desa Banua Halat}

Desa Banua Halat yang dahulu wilayahnya cukup luas, kini dimekarkan menjadi 16 kelurahan/desa dalam wilayah pemerintahan Kecamatan Tapin Utara, yakni: (1) Banua Halat Kiri (2) Banua Halat Kanan (3) Badaun, (4) Antasari Hilir, (5) Antasari, (6) Banua Hanyar, (7) Banua Hanyar Hulu, (8) Jingah Babaris, (9) Kakaran, (10) Keramat, (11) Kupang, (12) Lumbu Raya, (13) Perintis Raya, (14) Rangda Malingkung, (15) Rantau Kanan, dan (16) Rantau Kiwa. Apabila disebutkan nama "Banua Halat" saja, bisa berarti Banua Halat Kiri, Banua Halat Kanan, atau mewakili kawasan keenam belas desa tersebut.

Secara administratif desa-desa hasil pemekaran Banua Halat berada di dalam wilayah Kecamatan Tapin Utara, Kabupaten Tapin. Kabupaten Tapin dengan ibu kotanya Rantau, berada sekitar $\pm 130 \mathrm{~km}$ di arah utara Banjarmasin, ibu kota Provinsi Kalimantan Selatan. Berdasarkan letak geografisnya Kabupaten Tapin terletak di antara 20.32'.43" - 30.00'.43" Bujur Timur dan 1140.46'.13” -1150.30'33” Lintang Selatan. 
Kecamatan Tapin Utara yang terletak di bagian tengah Kabupaten Tapin meliputi 16 desa. Di Kecamatan Tapin Utara inilah terletak desa Banua Halat Kiri, lokasi Masjid Banua Halat yang menjadi tempat penyelenggaraaan upacara ba-ayun maulid.

Lokasi Desa Banua Halat Kiri mempunyai jarak tempuh sekitar 2,5 km ke ibu kota Kecamatan Tapin Utara, atau berjarak sekitar $2 \mathrm{~km}$ ke arah barat dari kota Rantau ibu kota Kabupaten Tapin dengan kondisi jalan yang relatif baik, atau berada sekitar $115 \mathrm{~km}$ di arah utara Banjarmasin, ibu kota Provinsi Kalimantan Selatan.

Desa Banua Halat Kiri dilintasi oleh Sungai Tapin yang posisinya berada sekitar 30 meter di sebelah timur Masjid Banua Halat. Sebelah utara masjid terdapat jalan desa, sekolah, madrasah dan kampung, sebelah barat terdapat kuburan muslimin dan rumah penduduk, dan di sebelah barat masjid ditumbuhi tanaman keras hasil budidaya dengan ketinggian antara 15-30 meter.

Desa Banua Halat Kiri mempunyai luas wilayah sekitar $2,5 \mathrm{~km}^{2}$. Sedangkan rata-rata ketinggian dari permukaan laut 8 meter dan keadaan suhu rata-rata 32 derajat celsius.

Desa Banua Halat Kiri dihuni oleh masyarakat Banjar subetnik Banjar Hulu. Jumlah penduduknya pada tahun 2007 mencapai 679 jiwa, terdiri atas 368 laki dan 311 perempuan. Dilihat dari indikator tingkat pendidikan, sebagian besar penduduknya hanya tamat SD/sederajat. Sebagian besar penduduknya bekerja di lahan pertanian sawah 375 orang, perkebunan 17 orang, dan jasa perdagangan 135 orang.

Banua Halat merupakan nama desa yang berusia tua. Pada abad ke-17 desa Banua Halat bersama-sama dengan Banua Padang, Banua Parigi, dan Banua Gadung dikenal dengan nama Banua Ampat. Keempat wilayah itu yang semuanya terletak di sepanjang tepian sungai merupakan identitas yang menunjuk wilayah dalam lingkungan Kerajaan Banjar. Ketika Kesultanan Banjar berdiri pada tanggal 24 September 1526 sebagai sebuah kerajaan Islam, Desa Banua Halat sebagai permukiman yang dihuni oleh komunitas sudah ada sebelum tahun tersebut.

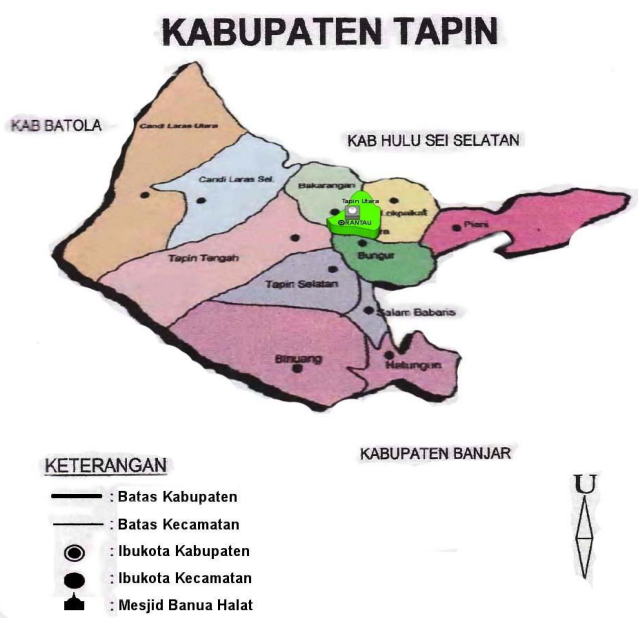

Gambar. 1 Peta lokasi Masjid Banua Halat. Sumber: BPS Kabupaten Tapin, 2007. Data Diolah.

Dalam terminologi penduduk Banua Halat dan sekitarnya, "banua" berarti kampung atau desa, sedangkan "halat" berarti perbatasan. Secara harfiah Banua Halat adalah kampung atau desa batas/perbatasan. Banua Halat dahulunya adalah kampung tempat tinggal nenek moyang Dayak Meratus. Di kampung ini terdapat dua orang bersaudara kandung yakni Intingan dan Dayuhan (Bondan, 1953: 182-183). Kemudian setelah agama Islam masuk dan tersebar di Banua Halat, penduduknya terbagi menjadi dua kelompok, yakni kelompok yang dipimpin Intingan (Palui Anum, Datu Ujung) memeluk agama Islam tetap tinggal di Banua Halat, sedangkan kelompok pimpinan Dayuhan (Palui Tuha) yang bertahan dengan kepercayaan lamanya berpindah ke daerah hulu sungai Pegunungan Meratus Tapin. Kelompok yang bertahan dengan kepercayaan lamanya itu disebut orang Bukit karena 
tinggal di bukit-bukit di pegunungan Meratus (kini populer dengan sebutan Dayak Meratus).

Sejak itulah dinamakan Banua Halat, karena menjadi kampung yang membatasi tempat tinggal masyarakat yang memeluk agama Islam dengan masyarakat yang tetap bertahan dengan kepercayaan lamanya. Meski demikian, perbedaan keyakinan di antara dua kelompok tidak menyebabkan persaudaraan mereka terputus. Mereka tetap berinteraksi sebagaimana biasa. Bahkan kelompok Dayuhan turut membantu saudaranya, kelompok Intingan dalam pembangunan Masjid Banua Halat.

Oleh karena itu, orang Dayak Meratus keturunan Dayuhan yang tinggal di Harakit, Batung, dan desa lainnya itu menyebut orang Banua Halat yang beragama Islam dengan sebutan dangsanak yang berarti saudara atau badangsanak (bersaudara), sebab mereka meyakini nenek moyang mereka bersaudara kandung dengan nenek moyang orang Banua Halat.

Adanya keyakinan adanya hubungan persaudaraan antara orang Dayak Meratus (keturunan Dayuhan) dan orang Banjar Hulu (keturunan Intingan) sesuai dengan beberapa publikasi, misalnya yang ditulis oleh Alfani Daud (1997), atau Noerid Haloei Radam (2001) yang menyimpulkan bahwa orang Dayak Meratus (orang Bukit) meyakini mereka memiliki "hubungan kekerabatan" dengan orang Banjar Hulu.

\section{Deskripsi U pacara Ba-ayun Maulid}

Upacara ba-ayun maulid

merupakan tradisi yang dilaksanakan turun temurun oleh masyarakat di Banua Halat Kabupaten Tapin dengan mengundang seluruh warga kampung dan bahkan di luar kampung.

Ba-ayun asal katanya "ayun" yang berarti "melakukan proses ayunan". Upacara ini disebut ba-ayun maulid, karena dilaksanakan pada peringatan Maulid Nabi Muhammad SAW, yakni bulan Rabiul Awal. Orang Banjar di Kalimantan Selatan juga sering menyebut maulid dengan sebutan "mulud" atau kadang "maulud", dan "bamulutan" untuk menyebut ber-maulidan. Upacara ini dilaksanakan di masjid. Oleh karena itu pada ruangan masjid digantungi ayunan (buaian) yang membentang pada tiangtiang masjid. Bagi warga asli (bahasa Banjar, bubuhan tutus) Desa Banua Halat, kain ayunan yang mereka gunakan ketika mengikuti upacara ba-ayun maulid disimpan sebagai benda pusaka yang disebut pikasih baranak terdiri dari 3 lapis, yakni kain sarigading (sasirangan), kain belacu warna kuning, dan tapih bahalai (kain panjang wanita).

Dahulu, upacara ba-ayun maulid hanya diikuti secara terbatas oleh anakanak warga bubuhan tutus yang lahir di Desa Banua Halat saja, namun sekarang bisa diikuti oleh siapa saja yang berminat, tidak memandang bubuhan tutus atau bukan, anak-anak, orang dewasa, atau kakek/nenek boleh menjadi peserta upacara ba-ayun maulid.

Para peminat yang berstatus bukan bubuhan tutus pada umumnya ikut upacara ba-ayun maulid karena motif atau kepentingan untuk membayar hajat, kaul, atau nazar, seperti: bebas dari jeratan hukum, sembuh dari penyakit, sukses meraih reputasi tertentu, dan lain sebagainya.

Bagi masyarakat umum, yang akan mengikuti prosesi ba-ayun maulid, kain ayunan yang digunakan adalah berupa: tapih bahalai tiga lembar, tali tiga meter, kakamban tiga lembar, dan biasanya sudah disediakan panitia.

Pada tali ayunan diberi hiasan berupa anyaman janur berbentuk burungburungan, ular-ularan, ketupat bangsul, halilipan, kambang sarai, rantai, hiasan berbentuk buah-buahan dan kue tradisional seperti : cucur, cincin, kue gelang, pisang, kelapa dan lain-lain. 


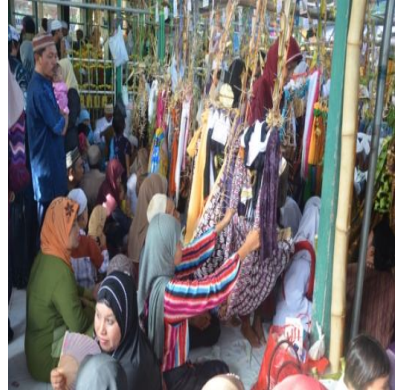

Gambar. 2. Ba-ayun maulid di Masjid Banua Halat.

Sumber: Wajidi.

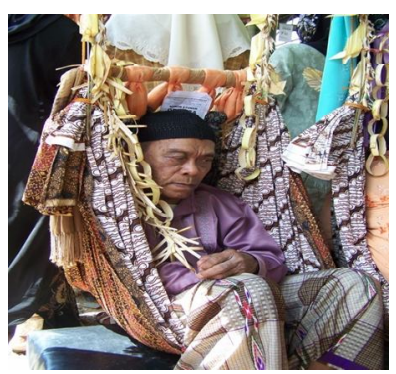

Gambar. 3. Peserta ba-ayun maulid dari Kalangan Orang Dewasa. Sumber: Wajidi.

Setiap orang tua yang ma-ayun anaknya pada upacara ini harus menyerahkan piduduk, yaitu sebuah sasanggan yang diisi beras kurang lebih 3 $1 / 2$ liter, sebiji gula merah, sebiji kelapa, sebiji telur ayam, benang, jarum dan sebongkah garam serta uang perak. Piduduk ini merupakan hadiah yang pada masa pra-Islam adalah simbol pengganti diri seseorang yang melaksanakan upacara untuk dipersembahkan kepada makhlukmakhluk halus yang datang atau diundang.

Upacara ba-ayun maulid di masjid dilaksanakan pada pagi hari dimulai pukul 10.00 , bertepatan dengan tanggal 12 Rabiulawal, hari kelahiran Nabi Muhammad SAW. Dalam upacara ba-ayun maulid ini dibacakan beberapa syair seperti syair Barzanji, syair Syarafal Anam dan syair Diba'i.

Anak-anak yang akan diayun dalam upacara tersebut, baru dibawa ke masjid menjelang tibanya pembacaan Asyrakal dan si anak langsung dimasukkan ke dalam ayunan yang telah disediakan. Tepat pada pembacaan asyrakal, anak yang ada dalam ayunan diayun secara perlahan, yakni dengan menarik selendang yang diikat pada ayunan tersebut. Maksud diayun pada saat itu adalah untuk mengambil berkah atas keluhuran dan kemuliaan Nabi Muhammad SAW yang kelahirannya diperingati saat itu. Semua anak yang diayun dalam masjid tersebut didoakan oleh pemuka agama (tuan guru) dan seluruh peserta upacara. Mereka semua berharap dan berdoa agar anak-anak tersebut kelak menjadi umat yang taat, bertakwa kepada Allah SWT dan RasulNya.

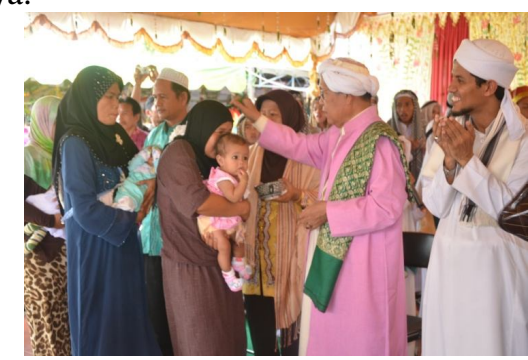

Gambar. 4. Doa Tuan Guru kepada Anak yang Ikut Berayun. Sumber: Wajidi.

\section{Pengaruh Tradisi Pra-Islam dalam U pacara Ba-ayun Maulid}

Upacara ba-ayun maulid yang diselenggarakan oleh masyarakat Banua Halat merupakan kegiatan yang telah mentradisi secara turun temurun. Tradisi ini merupakan sebuah proses kesinambungan mereka dengan masa lalunya ketika belum Islam. Akan tetapi, tujuan, perlengkapan, dan pelaksanaannya mengalami pergeseran, tidak persis sama dengan tradisi sebelumnya atau telah diisi dengan nilai-nilai Islam, meski diakui pula sebagian anasir-anasir lama masih dipertahankan.

Tradisi ba-ayun maulid juga telah menyatukan ikatan sosial berupa kekerabatan unilineal yakni menghubungkan silaturahmi para tutus atau juriat Banua Halat Halat yang tersebar di berbagai daerah dan "dunia 
lain", dan yang bukan tutus dengan jalan berkumpul di Banua Halat.

Upacara tersebut mengandung nilai budaya, tradisi, simbol, mitos dan sistem religi yang mencerminkan pengaruh unsur budaya atau tradisi pra-Islam.

Unsur budaya tampak pada kegiatan maayun anak dan pada perlengkapan seperti ayunan, hiasan janur, piduduk dan sasaji. Pengaruh budaya Islam tampak pada tempat upacara serta kegiatan mengayun anak bersamaan dengan peringatan maulid Nabi, atau mata acara yang terdiri atas pembukaan, pembacaan ayat Alqur'an, dan pembacaan Kitab Maulid.

Pengaruh tradisi pra-Islam antara lain tergambar pada maksud dan tujuan upacara, perlengkapan dan prosesi upacara, dan pada perlambangan atau simbolika pada bahan, warna, larangan atau pantangan dalam upacara yang dipengaruhi oleh unsur-unsur kepercayaan Kaharingan, Hindu, dan Islam.

Kesan sakral-religius dalam upacara ini tampak, terutama saat pembacaan kitab Maulid sampai pada "asyarakal" saat bersamaan anak-anak dibuai dalam ayunannya masing-masing, termasuk orang dewasa atau orang-orang tua yang ikut berayun. Keberadaan orang dewasa yang ikut berayun dilandasi oleh beberapa alasan atau keyakinan seperti untuk memenuhi nazar akan ikut berayun jika keinginan terwujud, atau misalnya karena adanya harapan akan kesembuhan dari sakit jika ikut berayun. Apalagi dalam pemahaman keagamaan sebagian masyarakat Banjar bahwa pada saat berayun itu Nabi Muhammad SAW datang memberikan berkah dan syafaat.

Pemahaman seperti ini rupanya mempunyai titik persamaan dengan paham terdahulu yang meyakini kehadiran Datu Ujung (Intingan/Palui Anum); tokoh pendiri Masjid Banua Halat dalam upacara ini. Kalangan orang-orang tua dahulu meyakini bahwa pada saat $b a$ ayun maulid yang hadir pada saat itu selain berkah dan syafaat Rasulullah
SAW, juga dapat merasakan kehadiran roh Datu Ujung sebagaimana terlihat dari beberapa kejadian kesurupan yang dialami beberapa orang. Oleh karena kesamaan itu, kedua unsur budaya ini dapat dipadukan dan lambat laun semakin jelas dominasi unsur budaya Islam.

Kepercayaan akan hadirnya roh Datu Ujung sangat erat kaitannya dengan tradisi asal (tradisi ma-ayun anak menurut kepercayaan Kaharingan) bahwa upacara maayun anak dilaksanakan dengan maksud dan tujuan agar keturunan mereka tidak mendapat gangguan dari makhlukmakhluk halus, seperti hantu, jin, setan, siluman, dan roh orang yang sudah meninggal dunia.

Tanda-tanda adanya pengaruh tradisi pra-Islam dapat dilihat pada kelengkapan upacaranya yaitu sasaji dan piduduk/sasarah. Pada masyarakat yang mempunyai paham pemujaan arwah nenek moyang, keduanya sangat penting artinya sebagai semacam persembahan sebagai perangkat pengganti diri agar terhindar dari gangguan makhluk halus. Pada tradisi yang dipengaruhi agama Islam, selain pada acara ba-ayun maulid, piduduk merupakan sesajian pada upacara batapung tawar, mandi-mandi pengantin, mandi-mandi kehamilan, dan lain-lain. Kalau ketinggalan sesajian piduduk ini dipercaya akan terjadi gangguan-gangguan yang tidak diinginkan. Masing-masing benda dari sasaji dan piduduk ini juga merupakan simbol penghargaan atau permintaan yang dihajatkan dalam upacara. Oleh karena itu, ada banyak makna perlambang pada bahan-bahan mentah yang terdapat pada piduduk. Misalnya, beras: diharapkan nantinya si anak selalu berkecukupan ekonominya, gula merah: agar si anak selalu manis dalam tindak-tanduk dan tutur katanya, kelapa: sering disebut lamak, agar si anak mendapatkan kelimpahan kebaikan/rezeki, dan sebagainya. 


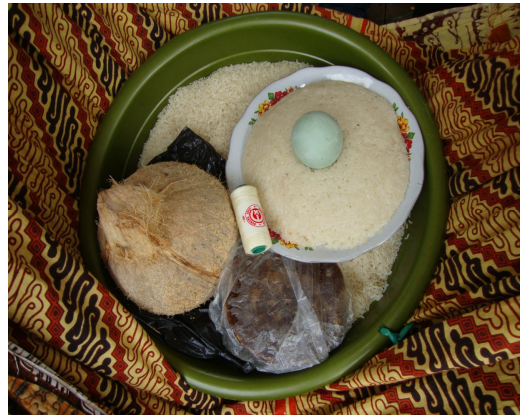

Gambar. 5. Piduduk. Sumber: Wajidi.

Simbol atau perlambangan ini juga terdapat pada bentuk-bentuk tertentu dari ayunan dan hiasan ayunan. Sebagian besar dari simbol-simbol tersebut masih dipertahankan sampai sekarang, meskipun piduduk dan sasaji pada hakikatnya telah berubah dari persembahan untuk arwah kini dipahami sebagai sedekah dan infak. Sasaji yang berupa telur masak dan nasi lamak merupakan sedekah untuk hadirin terutama anak-anak, sedangkan piduduk yang terdiri atas bahan-bahan mentah seperti kelapa, gula merah, beras, jarum, benang dan lain-lainnya merupakan sumbangan (infak) yang nantinya akan dilelang oleh panitia untuk kepentingan masjid.

Berdasarkan tradisi asalnya, tata cara maayun anak dalam upacara ba-ayun maulid sebenarnya berasal tradisi bapalas bidan sebagai sebuah tradisi yang berlandaskan pada kepercayaan Kaharingan. Ketika agama Hindu berkembang di daerah ini, berkembang pula budaya yang serupa dengan ba-ayun anak yakni ba-ayun wayang (didahului oleh pertunjukan wayang), ba-ayun topeng (didahului oleh pertunjukan topeng) dan ba-ayun madihin (mengayun bayi sambil melagukan syair madihin) (Hendraswati et al., 2012: 167)

Ketika Islam masuk dan berkembang, upacara bapalas bidan tidak lantas hilang, meski dalam pelaksanaannya mendapat pengaruh unsur Islam. Menurut
Alfani Daud (1997:240) seorang bayi yang baru lahir dinyatakan sebagai anak bidan sampai dilaksanakannya upacara bapalas bidan, yakni suatu upacara pemberkatan yang dilakukan oleh bidan terhadap si bayi dan ibunya. Upacara bapalas bidan dilaksanakan agar si bayi terhindar dari bahaya pengaruh magis dari bidan yang telah membantu proses kelahirannya, dan memastikan si bayi menjadi anak kedua orang tuanya. Jika upacara bapalas bidan tidak dilaksanakan, konon dapat menyebabkan si bayi sakit-sakitan.

Identifikasi upacara bapalas bidan menurut tradisi asal dapat dilihat upacara yang sekarang ini masih dipraktikkan orang-orang Dayak Meratus yang menganut kepercayaan Kaharingan. Bagi masyarakat Dayak Meratus, upacara bapalas bidan merupakan bagian yang tak terpisahkan dari upacara kehamilan. Kehamilan muda bagi orang Dayak Meratus adalah sebuah kegembiraan anugerah Ilah, mereka melakukan upacara kehamilan di umbun (rumah/bilik keluarga) dengan mengumpulkan sanakfamili dari umbun lainnya dalam satu bubuhan. Umumnya dilakukan di bilik umbun dan dipimpin oleh Balian Tuha, atau bisa juga Balian Tangah. Upacara ini cukup mereka sebut dengan bamandimandi, biasanya pada kehamilan (tian) 3 (tiga) sampai 7 (tujuh) bulan. Setelah bayi lahir, orang Dayak Meratus kemudian melaksanakan upacara bapalas bidan, yakni memberi hadiah (piduduk/sasarah) berupa lamang ketan, sumur-sumuran (aing terak), beras, gula dan sedikit uang kepada bidan atau balian yang menolong. Biasanya sekaligus pemberian nama kepada sang bayi. Termasuk nantinya saat anak sudah mulai berjalan (turun) ke tanah dari rumah (umbun) juga dengan upacara mainjak tanah, tetap dipimpin oleh balian.

Pada masyarakat Banjar yang masih memegang teguh tradisi lama, upacara seperti yang dilakukan orang Dayak Meratus juga dinamai upacara bapalas bidan, karena diadakan untuk menebus (palas) anak kepada bidan yang telah 
membantu persalinan. Juga dianggap sebagai penebus atas darah yang telah tumpah ketika melahirkan. Dengan pelaksanaan palas bidan ini diharapkan tidak terjadi pertumpahan darah yang diakibatkan oleh kecelakaan atau perkelahian di lingkungan tetangga maupun atas keluarga sendiri. Karena menurut kepercayaan darah yang tumpah telah ditebus oleh si anak pada upacara bapalas bidan tersebut.

Bagi masyarakat Banjar, bidan tidak saja membantu ketika mau melahirkan, tetapi sejak kehamilan sudah ikut menolong. Biasanya seorang bidan dimintai bantuan untuk mengetahui usia kehamilan dengan cara memegang (mengurut) perut, kemudian memberikan jamu-jamuan yang seharusnya boleh dimakan agar si ibu selalu sehat. Bidan ini juga secara rutin mengurut kandungan seorang ibu, supaya letak bayi dalam kandungan tidak sungsang. Oleh karena peranan bidan cukup menentukan, maka diadakanlah upacara bapalas bidan tersebut.

Oleh karena itu, tujuan diselenggarakannya upacara bapalas bidan ini adalah untuk menciptakan momentum bagi orang tua anak yang baru lahir untuk memberikan balas jasa kepada bidan yang telah berjasa menolong proses persalinannya hingga selamat tiada kurang suatu apa.

Fungsi upacara bapalas bidan merujuk pada solusi sosial budaya balas jasa berbasis ekonomi. Pada kesempatan ini orang tua dari anak yang kelahirannya ditangani oleh seorang bidan membalas jasa bidan yang bersangkutan dalam bentuk pemberian piduduk/sasarahan, yakni berupa 1 liter beras, 1 biji gula merah, 1 biji kelapa, dan rempah-rempah yang digunakan untuk memasak ikan.

Pemberian sasarah berasal dari tradisi lama, yakni ketika suku Banjar belum mengenal budaya uang. Balas jasa untuk orang lain diberikan dalam bentuk natura dan innatura, jadi jasa dibarter dengan natura atau innatura. Pada masa sekarang ini, balas jasa untuk seorang bidan atau dukun bayi sudah lazim diberikan dalam bentuk uang dengan besaran tertentu sesuai dengan azas kepatutan. Namun, tradisi pemberian sasarah hingga sekarang masih tetap dilakukan, hanya motifnya sudah bergeser sebagai simbol budaya saja.

Bapalas bidan biasanya dilakukan ketika bayi berumur 40 hari. Pada upacara bapalas bidan ini si anak dibuatkan buaian (ayunan) yang diberi hiasan yang menarik, seperti udang-udangan, belalang dan urung ketupat berbagai bentuk, serta digantungkan bermacam kue seperti cucur, cincin, apam, pisang, dan lain-lain.

Kepada bidan yang telah berjasa menolong persalinan itu diberikan hadiah segantang beras, jarum, benang, seekor ayam (jika bayi lahir laki-laki, maka diserahkan ayam jantan dan jika perempuan diberikan ayam betina), sebiji kelapa, rempah-rempah, dan bahan untuk menginang seperti sirih, kapur, pinang, gambir, tembakau dan berupa uang (Ideham ed. et al., 2007:76).

Ketika Islam datang ke daerah ini, acara bapalas bidan dan maayun anak tidak dilarang, hanya kebiasaan yang tidak sesuai sedikit demi sedikit ditinggalkan. Begitu pula berbagai perlengkapan, maksud dan tujuan, dan perlambang (simbolika) juga disesuaikan atau diisi dengan nilai-nilai Islam. Misalnya, peralatan dan bahan-bahan yang digunakan seperti ayunan, saji, piduduk, dan bahanbahan lainnya masih digunakan, akan tetapi dalam pelaksanaannya diikuti dengan ucapan Bismillaahirrahmaanirrahiim atau membacakan surah AlFatihah, pembacaan surah Yasin (QS:36), Salawat Nabi, dan pembacaan doa secara Islam, dan dilaksanakan bersama-sama di masjid bersamaan dengan peringatan maulid Nabi Muhammad SAW.

\section{Latar Belakang Munculnya Pengaruh Tradisi Pra-Islam}

Dalam upacara ba-ayun maulid sesungguhnya dapat ditelusuri adanya 
hubungan antara Islam dan kepercayaan lama yang terkait dengan proses Islamisasi di Nusantara umumnya dan di Kalimantan Selatan pada khususnya. Perilaku keagamaan masyarakat Banjar yang dekat dengan tradisi, tidak terlepas dari proses Islamisasi yang berlangsung secara damai, penuh toleransi dan persaudaraan, sebagaimana dapat dilihat, misalnya ketika masuknya Islam ke Banua Halat tidak lantas hubungan persaudaraan dua kelompok masyarakat yang berbeda keyakinan terputus, malahan mereka saling membantu membangun Masjid Banua Halat. Berbagai adat istiadat ketika Islam masuk dan berkembang tidak lantas hilang, malahan Islam memperkayanya dengan nilai-nilai Islam.

Hal demikian terjadi, karena Islam tersebar dengan damai, penuh toleransi dan persaudaraan. Toleransi dakwah Islam itu didukung oleh fleksibilitas (daya lentur) ajaran Islam itu sendiri. Dalam pengertian bahwa Islam merupakan kodifikasi nilainilai universal. Karenanya, ajaran Islam dapat berhadapan dengan berbagai bentuk dan jenis situasi kemasyarakatan. Dengan watak semacam ini, kehadiran Islam di suatu wilayah tidak lantas merombak tatanan nilai yang telah mapan (Huda, 2007:44).

Islam merupakan agama universal. Artinya Islam untuk seluruh umat manusia, bukan hanya tumbuh di Timur Tengah tapi juga di seluruh dunia. Karena Islam agama universal, ekspresi-ekspresi dalam bentuk mazhab, sekte, dan ritus-ritus keagamaan adalah sesuatu keniscayaan. Hal itu terjadi karena Islam berkembang dan dipahami tidak hanya bersifat tekstual, bahkan lebih dari itu yakni bersifat kontekstual sosiologis yakni adanya pengaruhpengaruh sosial budaya masyarakat terhadap Islam, sebagaimana tergambar dari adaptasi atau akulturasi Islam dengan kebudayaan. Oleh karena itu, Islam yang berkembang di Indonesia disebut dengan istilah "Islam Nusantara", yakni Islam yang berbeda dengan Islam yang ada di Arab.
Perbedaan itu bukan pada perbedaan pedoman. Alqur'an dan Sunnah Rasul tetap menjadi pedoman bersama, akan tetapi penafsiran dan ekspresinya yang dipengaruhi sosial budaya setempat mengakibatkan ritus-ritus keagamaan mempunyai perbedaan dengan daerah datangnya Islam. Atau dengan kata lain, karena adanya interaksi, adaptasi, dan akulturasi dengan budaya lokal, maka Islam yang masuk ke Indonesia bukanlah murni sebagaimana terdapat di daerah asalnya, melainkan sudah menjadi Islam yang dalam ekspresinya dipengaruhi oleh berbagai budaya atau tradisi di tempattempat ia berkembang.

Meski terdapat keragaman dalam praktik keagamaan di masyarakat, jelas tidak ada perbedaan di antara umat Islam pada level akidah. Oleh Azyumardi Azra (2002) perbedaan terutama terletak pada apa yang ia sebut sebagai "ranah budaya Islam" (Islamic cultural spheres) yang di antara satu komunitas Islam dengan dengan komunitas lainnya terdapat kekhususan (khas) dan distingsi tertentu. Salah satu perbedaan dan distingsi Islam Indonesia adalah apa yang disebut sebagai sinkretisme yang dipraktikkan sebagian kaum muslimin Indonesia, termasuk masyarakat Banjar yang mayoritas memeluk agama Islam.

Oleh karena itu, benar apa yang dikatakan oleh Muhammad Iqbal dalam Mujiburrahman (2012) bahwa agama adalah ekspresi keseluruhan jatidiri manusia. Menurut Iqbal, ketika dalam bentuk wahyu, agama bersifat ilahi. Tetapi ketika diterima manusia, ia meresap dalam seluruh relung kehidupan. Agama menjelma dalam pikiran, perasaan, dan tindakan manusia. Pemikiran Iqbal di atas mungkin dapat membantu kita mencermati perayaan Maulid Nabi Muhammad SAW yang selalu ramai dilaksanakan di setiap bulan Rabiul Awal, khususnya di masyarakat Banjar Kalimantan Selatan. Berbagai bentuk dan isi perayaan maulid itu memantulkan spektrum yang kaya dan 
saling melengkapi, atau bahkan bertentangan satu sama lain.

Menurut Wajidi (2011: 18-25) pada masyarakat Banjar di Kalimantan Selatan, akulturasi antara Islam dan kepercayaan lama dapat dilihat dari adanya tatanan nilai dan adat istiadat yang sangat dipengaruhi oleh agama Islam sebagai agama resmi kerajaan sejak abad ke-16, terutama ketika Kerajaan atau Kesultanan Banjarmasin berdiri pada tanggal 24 September 1526 sebagai sebuah kerajaan Islam atas bantuan Kerajaan Demak.

Jauh sebelum Kerajaan Banjar berdiri atas bantuan Demak, agama Islam telah masuk dan menyebar sampai ke daerah-daerah hulu sungai. Namun, setelah agama Islam dijadikan agama resmi kerajaan berkembang dengan pesat ke daerah pedalaman dan turut memengaruhi mitologi atau kepercayaan masyarakat setempat.

Dalam perkembangannya, Islam turut memengaruhi budaya dan kepercayaan masyarakat setempat yang sebelumnya berlandaskan pada kepercayaan nenek moyang (Kaharingan), Hindu, atau Budha sehingga memberikan ciri dan identitas tersendiri dalam budaya Banjar.

Kebudayaan Banjar berkembang paralel dengan sejarah asal-usul orang Banjar di Kalimantan Selatan. Masyarakat Banjar dikenal sebagai penganut agama Islam, namun dalam ritual-ritual tertentu kadang bernuasa sinkretis dengan unsur kepercayaan lama yang mereka warisi dari nenek moyang mereka (Bukit, Ngaju, Maanyan) sebagaimana terlihat hingga sekarang ini.

Kepercayaan yang mereka warisi itu pada dasarnya mengandung anasir animisme dan dinamisme yang telah terpatri dalam satu kesatuan menjadi kepercayaan yang dianut mereka. Adanya anasir animisme terlihat pada kepercayaan terhadap kekuatan gaib berupa roh-roh yang punya kekuatan tersendiri. Sedangkan anasir dinamisme terlihat dari adanya keyakinan bahwa benda-benda punya kekuatan tersendiri.

Setelah datangnya agama Hindu dan Islam, kepercayaan mereka mengalami perubahan atau pergeseran. Akan tetapi, unsur kepercayaan lama tidak hilang seperti percaya dengan kuyang-kuyang, hantu-hantu, ilmu kekebalan, roh-roh para pangeran, para dewa Batara Kala atau Sangkala, para leluhur-leluhur mereka seperti Datu Taruna (leluhur keluarga dalang Tulur di desa Barikin) Datu Thabib (leluhur famili Husna di Amuntai), Datu Ujung (pembangun masjid pertama di Desa Banua Halat Rantau), Datu Bungkul (pembangun Masjid Quba, Amawang Kanan Kandangan) dan makhluk-makhluk gaib lainnya.

Masyarakat Banjar selain mengakui adanya makhluk halus seperti makhluk jin dan hantu, juga mempercayai adanya orang gaib dari tokoh-tokoh terkemuka zaman dahulu yang berpindah tempat atau menjadi gaib (moksa) seperti wali-wali, raja-raja Banjar, atau datu-datu yang kehadirannya dapat dirasakan melalui gangguan kepada manusia atau dengan jalan merasuki raga orang-orang tertentu (Daud, 1989).

Orang gaib dari tokoh terkemuka itu menurut keyakinan mereka biasanya tidak tidak punya makam karena menurut mereka tokoh itu menjadi gaib atau tetap hidup di alam lain dan melalui perantaraan tutus atau juriatnya tokoh gaib itu melakukan komunikasi baik dengan tanda atau cara tertentu, misalnya dengan cara merasuki seseorang. Di antara tokoh yang diyakini menjadi gaib itu adalah Datu Ujung (tokoh pendiri Masjid Banua Halat), dan Datu Bungkul (tokoh pendiri Masjid Quba di Amawang Kanan).

Sebagian masyarakat Banjar juga punya hubungan denga makhluk halus dan peliharaan gaib. Selain itu juga percaya terhadap kekuatan gaib berupa roh-roh yang punya kekuatan tersendiri (animisme), dan mempercayai bendabenda punya kekuatan tersendiri (dinamisme) yang diyakini berada di luar 
jangkauan indera manusia. Benda-benda itu terkadang punya kekuatan positif dan terkadang juga punya kekuatan yang negatif.

Benda-benda yang dianggap punya kekuatan itu misalnya berupa pohonpohon kayu besar misalnya pohon kariwaya (beringin), tiang keramat, tempayan, kubur keramat, besi (keris, parang, tombak), batu akik, kain sarigading, kulit binatang, buntat atau tempurung kelapa yang tidak bermata, kalimbuai pusing (putar) kiri dan bijibijian dari buah tertentu. Benda yang demikian terkadang ada yang disimpan sebagai jimat atau syarat perlindungan diri. Benda-benda yang demikian kebanyakannya bersifat kekuatan positif.

Kepercayaan yang dianut, baik dari anasir anamisme maupun dinamisme adalah kepercayaan yang telah berurat berakar di tengah-tengah masyarakat, karena kepercayaan yang demikian merupakan kepercayaan turun temurun dari nenek moyang. Walaupun demikian kepercayaan terus menerus berkembang dan dalam pelaksanaanya disesuaikan dengan keadaan zaman, misalnya dengan diisi dengan nilai-nilai Islam, sebagaimana terlihat pada berbagai tradisi yang terkait dengan upacara daur hidup masyarakat Banjar di Kalimantan Selatan, seperti misalnya tradisi tolak bala, tradisi batapung tawar kehamilan, mandi tian mandaring (bapagar mayang), mandi baya, bapalas bidan, Ba-ayun Maulid yang merupakan suatu bentuk perpaduan tradisi lama dengan Islam. Oleh karena mendapat sentuhan Islam, bagi mereka yang mengerjakan, dianggap bukan membahayakan iman.

Pengaruh unsur agama Islam pada upacara-upacara tradisional seperti pada tradisi manyanggar banua terlihat pada setiap pembukaan selalu didahului dengan ucapan Bismillahirrahmaanirrahiim, setelah itu baru diteruskan seperti memanggil-manggil hantu-hantu, dewa-dewa, Batara Kala dan juga para wali, nabi-nabi dan lain-lainnya untuk mencicipi sesajen yang telah disediakan. Kemudian pada upacara penutup, setelah selesai mengembalikan hantu-hantu, dewa-dewa, Batara Kala dan lainlainnya, dari sesajen-sesajen yang ada itu dibacakan kembali doa selamat. Perkembangan selanjutnya, Islam memengaruhi sesajen. Yang diundang bukan lagi makhluk halus melainkan para tetangga atau kerabat. Mereka diundang untuk menghadiri selamatan, yakni berdoa selamat yang diringi dengan makan bersama. Hidangan tidak lagi dimaknai sebagai sesajen melainkan sedekah untuk para undangan.

Dari hal yang demikian itu dapat dikatakan bahwa berbagai upacara selamatan atau kenduri (aruh, bahasa Banjar) dengan mengundang orang banyak dengan menyediakan hidangan berupa makanan, kue-kue, dan minuman untuk disantap bersama dalam berbagai upacara daur hidup seperti pada saat kehamilan, kelahiran, perkawinan, pindah rumah, kematian, dan sebagainya berasal dari budaya lokal yakni sesajen yang telah mendapat pengaruh Islam. Sebagaimana dikatakan Clifford Geerzt (1995:77) bentuk ritual inti dari sinkretisme adalah sebuah perayaan bersama yang disebut slametan.

Begitulah halnya dengan adat istiadat, betapapun kuatnya perkembangan Islam yang tersebar di kalangan masyarakat Banjar sejak abad ke-16 sampai masa kehidupan Syekh Muhammad Arsyad al-Banjari (1710-1812 M) yang melalui kitab Tuhfah al-Raghibin bermaksud memurnikan akidah dari faham-faham bid'ah dan tradisi lama seperti upacara manyanggar banua dan mambuang pasilih, tidak lantas budaya lokal atau upacara-upacara yang berkaitan dengan unsur kepercayaan lama hilang begitu saja, dan bahkan pada kenyataannya sampai sekarang pun sisa-sisa kepercayaan lama itu masih ada di daerah tertentu, akan tetapi budaya lokal itu kemudian berakulturasi dengan Islam. 
Tata cara ma-ayun anak dalam upacara ba-ayun maulid yang berlangsung di Banua Halat sebenarnya berasal tradisi lama yakni upacara bapalas bidan sebagai sebuah tradisi yang berlandaskan pada kepercayaan Kaharingan. Ketika agama Hindu berkembang di daerah ini, berkembang pula budaya yang serupa dengan ba-ayun anak yakni ba-ayun wayang (didahului oleh pertunjukan wayang), ba-ayun topeng (didahului oleh pertujukan topeng) dan ba-ayun madihin (mengayun bayi sambil melagukan syair madihin).

Oleh karena mengayun anak bersamaan dengan bapalas, kadang disebut ba-ayun bidan yang maksudnya upacara mengayun oleh bidan. Seorang bayi yang baru lahir dinyatakan sebagai anak bidan sampai dilaksanakannya upacara bapalas bidan, yakni suatu upacara pemberkatan yang dilakukan oleh bidan terhadap si bayi dan ibunya.

Selain bersamaan denga bapalas bidan, upacara ma-ayun anak ada yang dilaksanakan bersamaan dengan perayaan maulid Nabi Besar Muhammad SAW tanggal 12 Rabiul Awal sehingga disebut ba-ayun maulid atau ayun mulud, yakni upacara mengayun bayi sambil membaca syair maulid, sebagaimana berlangsung di Desa Banua Halat, Kabupaten Tapin.

Menurut catatan sejarah, ba-ayun anak semula adalah upacara peninggalan nenek moyang orang Banjar yang masih beragama Kaharingan. Tetuha masyarakat setempat menyatakan bahwa tradisi ini semula hanya ada di Kabupaten Tapin (khususnya di Desa Banua Halat Kecamatan Tapin Utara). Namun kemudian berkembang dan dilaksanakan di berbagai daerah di Kalimantan Selatan.

Tradisi ini menjadi penanda konversi agama orang-orang Dayak yang mendiami Banua Halat dan daerah sekitarnya, yang semula beragama Kaharingan kemudian memeluk agama Islam. Karena itu upacara ba-ayun anak tidak bisa dilepaskan dari sejarah masuknya Islam ke daerah ini.
Sebelum Islam masuk, orang-orang Dayak Kaharingan yang berdiam di desa Banua Halat biasanya melaksanakan upacara aruh ganal. Setelah Islam masuk dan berkembang serta berkat perjuangan dakwah para ulama, akhirnya upacara tersebut bisa diislamisasikan. Bacaanbacaan balian (tetuha adat), bamamang, mantra-mantra, doa, dan persembahan kepada para dewa dan leluhur, nenek moyang di Balai, akhirnya digantikan dengan pembacaan syair-syair maulud, yang berisi sejarah, perjuangan, dan pujian terhadap Nabi Muhammad SAW, dilaksanakan di masjid, sedangkan sistem, perlengkapan, dan pola pelaksanaan upacara tetap. Akulturasi terhadap tradisi ini terjadi secara damai dan harmonis serta menjadi substansi yang berbeda dengan sebelumnya, karena ia berubah dan menjadi tradisi baru yang bernafaskan Islam.

Oleh karena memang berasal dari tradisi pra-Islam, maka di antara perlengkapan ba-ayun maulid yang diselenggarakan di masjid Banua Halat terdapat banyak persamaan dengan perlengkapan langgatan pada acara tradisional aruh ganal yang dilaksanakan orang Dayak Meratus di daerah Mancabung, Harakit, Balawaian, Batung, Danau Darah, dan Ranai, di sepanjang hulu dari Sungai Tapin. Persamaan itu seperti piduduk yang berisi beras, kelapa, gula dan garam.

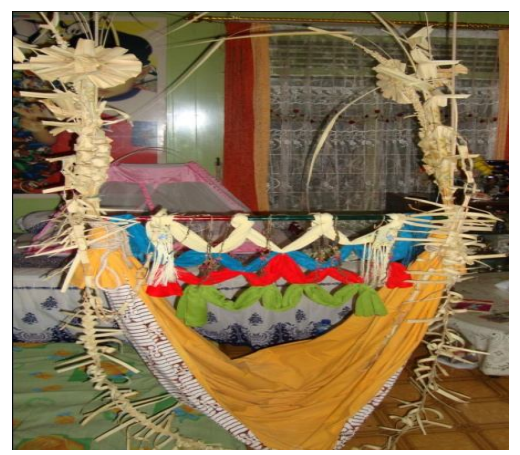

Gambar 6. Hiasan Janur pada Ayunan. Sumber: Wajidi. 


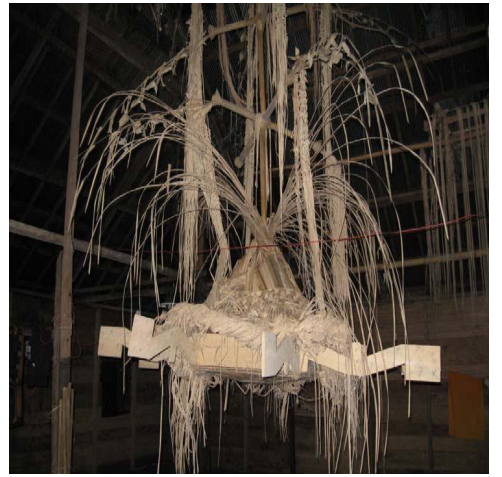

Gambar 7. Hiasan Janur pada Langgatan.

Sumber: Wajidi.

Persamaan lainnya adalah ada pada perhiasan kembang ayunan yang terbuat dari daun kelapa muda (janur), terdiri atas macam bunga-bungaan, tangga puteri, tangga pangeran, payung singgasana, tuhu komando, sapit hundang, ular-ular, dan kakapit. Hiasan tujuh hiasan itu juga dipakai pada hiasan langgatan yang ada di rumah adat Balai Dayak Meratus.

Nilai utama yang hendak ditanamkan oleh para ulama dalam upacara ba-ayun anak dan mengisinya dengan pembacaan syair-syair maulid di Desa Banua Halat tersebut tidak lain sebagai bagian dari strategi dakwah kultural yang dilakukan para ulama pada saat Islam memasuki Desa Banua Halat. Strategi ini dilakukan melalui pendekatan aspek penjelasan dan tindakan yang bersifat sosiokultural dan keagamaan, jadi bukan dengan pendekatan politik, salah satunya adalah dengan menggunakan medium seni budaya.

Dengan model dakwah itu, mereka tetap menjaga dan melestarikan sebuah tradisi dengan prinsip setiap budaya yang dipandang tidak merusak akidah dapat dibiarkan hidup atau berkembang di masyarakat.

Berdasarkan kenyataan di atas, $b a$ ayun anak adalah salah satu simbol pertemuan antara budaya dan ajaran agama. Mengayun anak, jelas sebuah tradisi lokal yang dilakukan oleh masyarakat Banjar dan Dayak secara turun-temurun dari dahulu hingga sekarang untuk menidurkan anak-anak. Sedangkan memberi nama anak, berdoa, membaca shalawat, atau pun membaca Alqur'an, dan silaturahmi merupakan anjuran dan perintah agama. Kedua ritus secara harmoni telah bersatu dalam kegiatan $b a$ ayun anak, yang bahkan secara khusus dilaksanakan pada bulan Rabiul Awal sebagai peringatan sekaligus penghormatan atas kelahiran Nabi Muhammad SAW.

Oleh karena itu dapat dipahami bahwa pada upacara daur hidup termasuk ba-ayun maulid yang dilaksanakan masyarakat Banjar terdapat unsur Islam yang beralkulturasi dengan unsur kepercayaan lama. Proses akulturasi keduanya bersifat timbal balik yakni unsur kepercayaan lama tidak hanya memengaruhi masyarakat Islam namun sebaliknya Islam juga memengaruhi sistem kepercayaan orang Dayak Meratus yang menganut kepercayaan Kaharingan. Pada masyarakat Islam, akulturasi tergambar pada tradisi dan praktik keagamaan yang mendapat pengaruh unsur-unsur kepercayaan lama, sedangkan pada masyarakat Dayak Meratus adalah dikenalnya nama Tuhan, malaikat, dan nabi-nabi agama Islam dalam sistem kepercayaan mereka.

Adanya unsur-unsur kepercayaan lama dalam tradisi dan praktik keagamaan masyarakat Islam dapat dimaknai bahwa proses Islamisasi hingga sekarang ini belum selesai, sedangkan adanya unsurunsur Islam dalam sistem kepercayaan Dayak Meratus menunjukkan kemungkinan terjadinya proses Islamisasi yang terputus di kalangan nenek moyang orang Dayak Meratus, di samping kemungkinan adanya pengaruh interaksi yang intensif antara masyarakat yang memeluk agama Islam dan yang bertahan dengan kepercayaan lamanya. Di Banua Halat, perbedaan keyakinan di antara dua komunitas tindak menyebabkan persaudaraan mereka terputus. Mereka tetap berinteraksi sebagaimana biasa. 
Kelompok Dayuhan yang bertahan dengan kepercayaan lamanya turut membantu saudaranya yang muslim dalam pembangunan Masjid Banua Halat dan menyaksikan ritus agama Islam yang dijalankan kelompok Intingan. Interaksi demikian mengakibatkan kelompok Dayuhan mengenal nama Tuhan, malaikat, dan nabi-nabi yang diyakini oleh kelompok Intingan

\section{PEN UTUP}

Dari paparan di atas dapat dikemukakan bahwa Banua Halat merupakan kawasan permukiman tua. Dahulunya pernah dihuni komunitas praIslam yang cukup lama dan berlanjut sampai datangnya pengaruh Islam di Kalimantan Selatan. Sebagai kawasan yang pernah dihuni sejak masa pra-Islam, berbagai tradisi dan kepercayaan seperti upacara ba-ayun maulid yang diselenggarakan di Masjid Banua Halat Kabupaten Tapin merupakan salah satu bentuk cerminan akulturasi antara Islam dengan budaya lokal.

Upacara ba-ayun maulid yang diselenggarakan oleh masyarakat Banua Halat merupakan kegiatan yang telah mentradisi secara turun temurun. Tradisi ini merupakan sebuah proses kesinambungan mereka dengan masa lalunya ketika belum Islam. Akan tetapi, tujuan, perlengkapan, dan pelaksanaannya mengalami pergeseran, tidak persis sama dengan tradisi sebelumnya atau telah diisi dengan tataran nilai-nilai Islam, meski diakui pula sebagian anasir-anasir lama masih dipertahankan.

Maksud diadakannya tradisi $b a$ ayun maulid adalah sebagai suatu ungkapan rasa syukur kepada Allah subhanahu wa taala atas limpahan rahmat dan karunia-Nya atas kelahiran Nabi Muhammad SAW yang membawa rahmat bagi sekalian alam. Adanya puji-pujian dan shalawat yang menyertai peringatan maulid Nabi merupakan simbol akan kecintaan kepada Nabi dan sekaligus harapan umat Islam yang selalu mengenang, meneladani kehidupan, dan mengharap syafaat dari Rasulullah SAW kelak di yaumil akhir.

Ba-ayun maulid juga berfungsi untuk menghubungkan silaturahmi para tutus atau keluarga besar juriat Banua Halat Halat yang tersebar di berbagai daerah atau bahkan yang berada di "dunia lain" dengan jalan berkumpul di Banua Halat, di samping banyaknya orang yang bukan tutus Banua Halat yang datang untuk menjadi peserta ba-ayun maulid.

Benda-benda peralatan upacara $b a$ ayun maulid selain mempunyai kegunaan praktis ada juga yang mempunyai fungsi tertentu sesuai dengan filosofi upacara. Namun demikian, secara keseluruhan, masing-masing benda tersebut mempunyai makna perlambang yang merupakan perwujudan dari harapan, tujuan atau hajat dari yang melaksanakan upacara sebagai cerminan dari pengaruh unsur kepercayaan lama.

Ritual mengayun anak bersamaan dengan tradisi ba-ayun maulid pada mulanya tidak lepas dari anggapan hadirnya Datu Ujung pada saat acara berlangsung, bahwa anak yang tidak diayun mungkin mengalami kesulitankesulitan seperti penangisan, kapidaraan, dan sebagainya. Oleh karena itu, mengikutsertakan anak dalam Ba-ayun merupakan suatu ikhtiar agar terbebas dari gangguan Datu Ujung atau tidak "katagihan datu". Namun, tradisi mengayun anak bersamaan dengan upacara maulid nabi juga dimaksudkan untuk "menghadirkan" Rasulullah SAW., sehingga nantinya anak yang diayun dapat mewarisi sifat-sifat mulia Rasullullah SAW.

Upacara ba-ayun maulid di Desa Banua Halat sebenarnya berasal tradisi maayun anak yang dilaksanakan pada acara bapalas bidan, yakni sebuah tradisi dalam budaya pra-Islam yang hingga kini masih dipraktikkan oleh orang Dayak Meratus. Ketika Islam datang ke daerah ini, acara bapalas bidan dan maayun anak 
tidak dilarang, hanya kegiatannya dilakukan bersama-sama, ditambah dengan doa-doa, serta dilaksanakan di dalam masjid bersamaan dengan peringatan maulid Nabi Muhammad SAW, tanggal 12 Rabiul Awal. Tradisi maayun anak yang penyelenggaraannya bersamaan dengan maulid Nabi Muhammad SAW itu akhirnya dikenal dengan nama ba-ayun maulid.

Perlengkapan ba-ayun maulid yang diselenggarakan di masjid Banua Halat memiliki banyak persamaan dengan perlengkapan langgatan pada acara tradisional aruh ganal yang dilaksanakan orang Dayak Meratus di daerah Mancabung, Harakit, Balawaian, Batung, Danau Darah, dan Ranai, di sepanjang hulu dari sungai Tapin. Persamaan lainnya ada pada piduduk yang berisi beras, kelapa, gula dan garam. Persamaan itu menunjukkan adanya keluwesan agama Islam dalam menghadapi kultur lokal. Benda-benda peralatan upacara, harapan atau simbol tertentu, tidak dipermasalahkan atau tetap dipertahankan. Akan tetapi yang berkaitan dengan persembahan, simbol tersebut diberi makna atau nilai baru yaitu sebagai sedekah.

Adanya upacara selamatan dengan mengundang orang banyak, didahului dengan doa-doa, dan menyantap hidangan berupa makanan, kue-kue atau penganan, dan minuman secara bersamasama termasuk menyantap penganan sesudah ba-ayun maulid, sesungguhnya berasal dari budaya lokal, yakni sesajen yang telah mendapat pengaruh Islam.

Adanya interaksi atau persinggungan antara Islam dan unsur kepercayaan lama dalam upacara ba-ayun maulid dapat dipahami bahwa ketika Islam masuk dan berkembang di Kalimantan Selatan tidak lantas berbagai tradisi atau upacara adat yang berkaitan dengan kepercayaan lama hilang begitu saja. Yang terjadi adalah tradisi itu tetap dipertahankan dan malahan Islam memengaruhi kepercayaan masyarakat setempat yang sebelumnya berlandaskan pada kepercayaan lama sehingga memberikan ciri dan identitas tersendiri dalam budaya Banjar. Pada upacara $b a-$ ayun maulid yang dijalankan masyarakat Banjar khususnya yang diselenggarakan di Masjid Banua Halat sisa-sisa kepercayaan lama itu masih ada, namun telah berakulturasi dengan Islam.

\section{DAFTA R SU MBER}

\section{Buku}

Azra, Azyumardi. 2002.

Islam Nusantara: Jaringan Global dan Lokal. Bandung: Mizan.

BPS Kabupaten Tapin. 2007. Kabupaten Tapin dalam Angka Tahun 2007. Rantau.

Bondan, Amir Hasan Kiai. 1953. Suluh Sedjarah Kalimantan. Banjarmasin: Fadjar.

Danandjaja, James. 1986.

Foklor Indonesia, Ilmu Gosip, Dongeng, dan lain-lain. Jakarta: Pustaka Grafitipers.

Daud, Alfani. 1997. Islam dan Masyarakat Banjar: Diskripsi dan Analisa Kebudayaan Banjar. Jakarta: Raja Grafindo Persada.

Geerzt, Clifford. 1995.

Kebudayaan dan Agama. Terjemahan Fransisco Budi Hardiman. Yogyakarta: Kanisius.

Hendraswati, Wajidi, Tajuddin Noor Ganie, Syarifuddin R. 2012.

Upacara Daur Hidup Masyarakat Suku Banjar di Kalimantan Selatan. Pontianak: Balai Pelestarian Nilai Budaya.

Huda, Noor. 2007.

Islam Nusantara Sejarah Sosial Intelektual Islam di Indonesia. Jogjakarta: Ar-Ruzz Media.

Ideham, M. Suriansyah, Sjarifuddin, Gazali Usman, M. Zainal Arifin Anis, Wajidi (ed.). 2007. 
Urang Banjar dan Kebudayaannya. Banjarmasin: Badan Peneliti-an dan Pengembangan Daerah Provinsi Kalimantan Selatan.

Koentjaraningrat. 1989.

Pengantar Ilmu Antropologi. Jakarta: Aksara Baru.

Kuntowijoyo. 2001. Muslim Tanpa Masjid, Essai-Essai Agama, Budaya, dan Politik dalam Bingkai Strukturalisme Transendental. Bandung: Mizan.

Nottingham, Elizabeth K. 2002.

Agama dan Masyarakat, Suatu Pengantar Sosiologi Agama. Terjemahan Abdul Muis Naharong. Jakarta: Raja Grafindo Persada.

Radam, Noer'ied Haloei. 1994. Religi Orang Bukit. Cetakan I. Yogyakarta: Penerbit Semesta.

Sedyawati, Edi. 2012.

Budaya Indonesia, Kajian Arkeologi, Seni, dan Sejarah. Jakarta: Raja Grafindo Persada.

Sjamsuddin, Helius. 2012.

Metodologi Sejarah. Yogyakarta: Ombak.

Sztompka, Piotr. 2008.

Sosiologi Perubahan Sosial. Dialihbahasakan oleh Alimandan. Jakarta: Prenada.

Wajidi. 2011.

Akulturasi Budaya Banjar di Banua Halat. Yogyakarta: Pustaka Book Publisher.

\section{Laporan Penelitian}

Abbas et al. 1994/1995. Upacara Ba-ayun Mulud di Banua Halat Kabupaten Tapin. Banjarbaru: Museum Negeri Lambung Mangkurat.

\section{Surat Kabar}

Mujiburrahman

"Sisi Manusia Agama". Banjarmasin Post. 6 Februari 2012, hlm. 12.

\section{Sumber Lisan/Informan}

Ibnu Mas'ud, S.IP (50 tahun). 2012. Kabid Kesenian dan Kebudayaan pada Disporabudpar Kab. Tapin. Juni 2012.

Yahya (57 tahun). 2010. Penjaga (kaum) Masjid Banua Halat, Kamis 25 Februari 2010.

Hj. Badariah (62 tahun). 2012. Ibu Rumah Tangga, Banjarmasin. Juni 2012.

Drs. H. Syamsiar Seman (76 tahun). 2012. Pensiunan PNS/ Budayawan, Banjarmasin. Juli 2012.

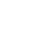

